\title{
Growing Thanks to Whom? The Impact of Staff on Demand on Organizational Growth Dynamics: Evidence from Sweden
}

\author{
Leonardo Pompa ${ }^{1}$ \\ ${ }^{1}$ Department of Communication and Economics, University of Modena and Reggio Emilia, Italy \\ Correspondence: Leonardo Pompa, Department of Communication and Economics, University of Modena and \\ Reggio Emilia, viale A. Allegri, 9, 42121 Reggio Emilia, Italy. Tel: 39-0522-523-200. E-mail: \\ leonardo.pompa@unimore.it
}

Received: November 9, 2020

Accepted: December 6, $2020 \quad$ Online Published: December 20, 2020

doi:10.5539/ijef.v13n1p80

URL: https://doi.org/10.5539/ijef.v13n1p80

\begin{abstract}
Young fast-growing companies operating in the digital economy represent a tendency which has, so far, been little explored by academic literature that has, until now, not been able to form a systematic approach to this topic. Among the many factors that can help to explain their rapid evolutionary dynamics, some researchers (Ismail, 2013; Burke, 2015) underline the so-called use of Staff on Demand, that is to say freelance workers. In other words, freelance personnel. One usually thinks that not having stable relationships with the companies for which they work, contractors can help to streamline organizational processes and therefore favour faster growth. By means of a multiple case study, this paper will show that, contrary to belief, Staff on Demand represents an important but not crucial presence for fast-growing companies. The case study was carried out on a number of recently formed Swedish companies. The collection of data and the interviews with their founders, CEOs and HR Officers, clearly show that the most important role is still played by full time employees and that the presence of Staff on Demand does not affect in any substantial way the growth of a company or of Human Resource management.
\end{abstract}

Keywords: staff on demand, organizational rapid growth, emerging HRM practices, case study research

\section{Introduction}

It is an undeniable fact that the labor market is becoming ever increasingly more flexible (Süß \& Kleiner, 2010) and that the importance of freelancers within modern businesses, especially fast-growing business, is continuously on the increase (Ismail, 2013). Many businesses prefer resorting to freelance workers for a wide range of activities and this tendency could lead us to believe that traditional contractual employees are losing their importance in business growth strategies. If, on the one hand, it is undoubtedly true that today the economic context in which business operate has changed with regards to human resources, it is also true that there is no clear indication of the precise roles played by freelancers and fulltime employees in the growth process of businesses, and especially of the younger businesses. Managerial literature has not yet dealt with this topic and there are still very few empirical studies focusing on the rapport between business performance and the type of personnel employed. This subject is particularly interesting if one considers businesses that grow rapidly, in a just a few years and sometimes, in just a few months from their foundation. According to Ismail (2013) these so-called exponential organizations grow at a staggering rate thanks to one fundamental presence: staff on demand. All freelance workers who have no fixed or continuous contracts with the business for which they work, fall into this category. Ismail asserts that staff on demand is an essential element for any organization wishing to grow rapidly. He states that "no matter how talented your employees, chances are that most of them are becoming obsolete and uncompetitive right before your eyes ... for any company today having a permanent, full-time workforce is fraught with growing peril as employees fail to keep their skills up to date" (Ismail, 2013). But are we sure about this? Are organizational processes that determine the growth of young companies really based on the role of freelancers? This study will try to answer such questions with a qualitative approach, concentrating on a multiple case study concerning five young Swedish businesses. Emerging literature focusing on these themes often tell us about what happens in Silicon Valley or, more generally, in the United States (Miller \& Côté, 1985; Frick, 2016). It will be interesting then to look at what happens in Europe, where Sweden undoubtedly represents a shining example of a nation that provides huge incentives to businesses, especially with 
regards to startups. Standing out on the Swedish scene is its capital Stockholm, a city with 900,000 inhabitants that attracts into its confines an extremely high number of "unicorns" or, in other words, fast-growing businesses (Knowledge@Wharton, 2015). With this case study, we will try to determine whether the presence of freelance workers is important or otherwise for the rapid growth of the organizations taken into consideration and in which fields these workers are most widely used. We will have to use a qualitative approach due to the fact that no database is available providing the precise numbers of contractors used by each of these businesses. It is relatively easy to establish the number of stable workers employed by a particular company, but almost impossible to know how many non-stable workers they use. One hopes that, in the future, data can be gathered on this category of worker that will help in carrying out empirical and quantitative research on this topic.

The results of this case study illustrate that the role played by stable workers is still crucial for the growth of a business. This seems to at least partially contradict the theories of those who believe that high organizational performance can not be achieved without resorting to freelance workers (Malone et al., 2011; Ismail, 2013; Johns \& Gratton, 2013).

\section{Why Sweden?}

Over the past few years, the number of startups founded in Sweden has risen enormously, so much so that that some experts claim that this Scandinavian country and, in particular, its capital, are Silicon Valley's true rivals, especially with regards to young companies operating in the technology sector (Benwell, 2014). The Swedish ecosystem, so favorable to businesses, has seen the birth of hugely successful companies, the latest of which is undoubtedly Spotify. It is not easy to identify all of the elements that helped to make this company such a success, but it has to be acknowledged that Sweden has invested massively over the years in creating ICT infrastructures, which represent the true driving force of the current digital revolution. On top of that, Sweden has grown at a vertiginous pace thanks to its efficient educational system which, at a university level, concentrates heavily on subjects concerning engineering and information technology programming. As stated by the OECD, 3.3\% of Sweden's gross national product is devolved to research, compared to an average of $2.3 \%$ devolved by the other OECD countries (Gaitzsch, 2016). So-called "global thinking" is also very widespread in the whole of the country, which creates a tendency to develop personal and work based links with people and organizations from outside the national borders. This undoubtedly means that people are influenced by circumstances foreign to their everyday reality enabling them to expand their thoughts without confines. From a business point of view, young Swedish business people are constantly looking for original ideas and new connections with foreign companies and institutions, especially in the United States. A successful example of this is Silicon Vikings, a network of companies with a thousand or so affiliates and with the aim of giving birth to a business community in which Scandinavian business people can work in close connection with their colleagues in Silicon Valley, making their ecosystem of innovation even more solid. It is these very people, with their immense baggage of intellectual capital, that supply the impulse to all the successful projects that the Scandinavian countries are currently experiencing, as human resources are, probably, the main resource that allows these innovative small Nordic businesses to be competitive (Tovstiga \& Tulugurova, 2009). Today, Sweden can count on a population that is inclined to internationalization and which is very skilled in the use of new technologies. Since the 90 's, the government has granted allowances to families for purchasing computers. It is estimated that today about $90 \%$ of Swedish households have internet connection. Those who in the 90's were little more than kids, have grown up in a culture that considers the presence of technology in everyday life as being normal. Everything we have mentioned so far would lead us to believe that the leadership of Sweden, and of Stockholm in particular, has been incontestable. In actual fact, however, Swedes have to cope with a series of restrictive elements, most notably: house prices, taxation and legislative barriers (Gaitzsch, 2016). While politicians are trying to make these factors less hostile to businesses, some startups have decided to move their head offices to Germany. An example of this is SoundCloud, an online musical platform that moved to Berlin for cutting costs. In conclusion, we can state that on the one hand Sweden quite rightly continues to invest in its strong areas, enabling the birth of an ever increasing number of innovative domestic businesses, while on the other hand there are a number of problems that make the country struggle to keep these businesses for any lengthy period of time. The risk is, in fact, that of some of leading companies leaving the country after their foundation, with inevitable and negative consequences regarding unemployment and economic growth. As proof of the enormous potential this Scandinavian country is able to generate, let's consider those shining business examples that have experienced staggering growth over the past few years: Spotify, Mojang, Skype, Klarna and King.

Spotify is, without doubt, one of the leading musical platforms worldwide. With over 75 million active users and reaching 58 countries, the company today has an estimated value of 8.53 billion dollars. Mojang is itself another 
flagship of the Swedish economy. Founded by Markus Persson in May 2009, Mojang was acquired by Microsoft in 2014 at a cost of 2.5 billion dollars. Skype, which is the most widely used Instant Messaging service in the world, was founded in 2003 by the Swede Niklas Zennström in collaboration with his Danish and Estonian colleagues. Since its foundation, the company has been the subject of four acquisitions, the last of which was in 2011 when it was acquired by Microsoft for a sum of 8.5 billion dollars. This all goes to show how attractive the business had become in the years immediately following its foundation.

Alongside these companies, there is a wide array of other small business that continue to emerge everyday. Of course, not all of them will reach the growth level of Skype or Spotify, but the mere fact that there are so many business initiatives is solid proof of how the Swedish economical context is considered to be favorable by young Swedish business people.

\section{Methodology}

With this study, we will try to comprehend which role Staff on Demand plays within young fast-growing companies from at least two different points of view, which are summed up in the following research questions:

1st RQ: Does the presence of Staff on Demand influence the way in which Human Resource processes are organized and managed?

$2 n d R Q$ : Is the presence of Staff on Demand really crucial for a fast-growing young company?

In order to answer these questions, we will use a multiple case study based on a qualitative approach. The aim is that of contributing to the creation of a detailed and systematic study into the expansion dynamics of young fast-growing companies. The use of this type of approach can be useful when dealing with questions that researchers have not yet posed or questions that have not yet been adequately researched (Eisenhardt \& Graebner, 2007) which, in the case of fast-growing companies, is particularly true. As Eisenhardt (1989) reminds us, those who carry out research into businesses, usually develop their theories basing themselves on pre-existing literature regarding a certain topic. In this case, this choice would be unfeasible due to the fact that there is very little material available on the topic we are dealing with. Research being carried out by the use of case studies continues to meet with increasing success (Yin, 2013), proving that it is valid and perfectly suitable approach for developing new areas of research into fields which have so far been rarely investigated.

Companies with similar business lines were chosen and all of them operate in the field of new technology and have a strong innovative vocation with strong emphasis on digitalization. The only company that differs is Orbital Systems which offers services and products very different to businesses that work in the field of cyber security or website creation. Orbital Systems, in fact, works in the field of water recycling and the choice of including such a company is not casual. It helps us to understand if the management dynamics and the importance of Staff on Demand depend on the type of business a company is involved in. As we will see, the fact that Orbital Systems operates in a field that tends to be different from the other four companies, does not appear to mean that it has a different approach to Human Resource management or a different way of dealing with company growth. The case study was initiated starting from the collection of data relating to various key indicators (sales, profit, number of customers/users, number of stable employees and the number of contractors) and then to interviewing the Human Resource managers, CEO's and founders of various companies. The results are presented in a synthetic form in Table 2. In the next sections we will go more in depth into methodological aspects.

Table 1. A synthesis of the methodology adopted

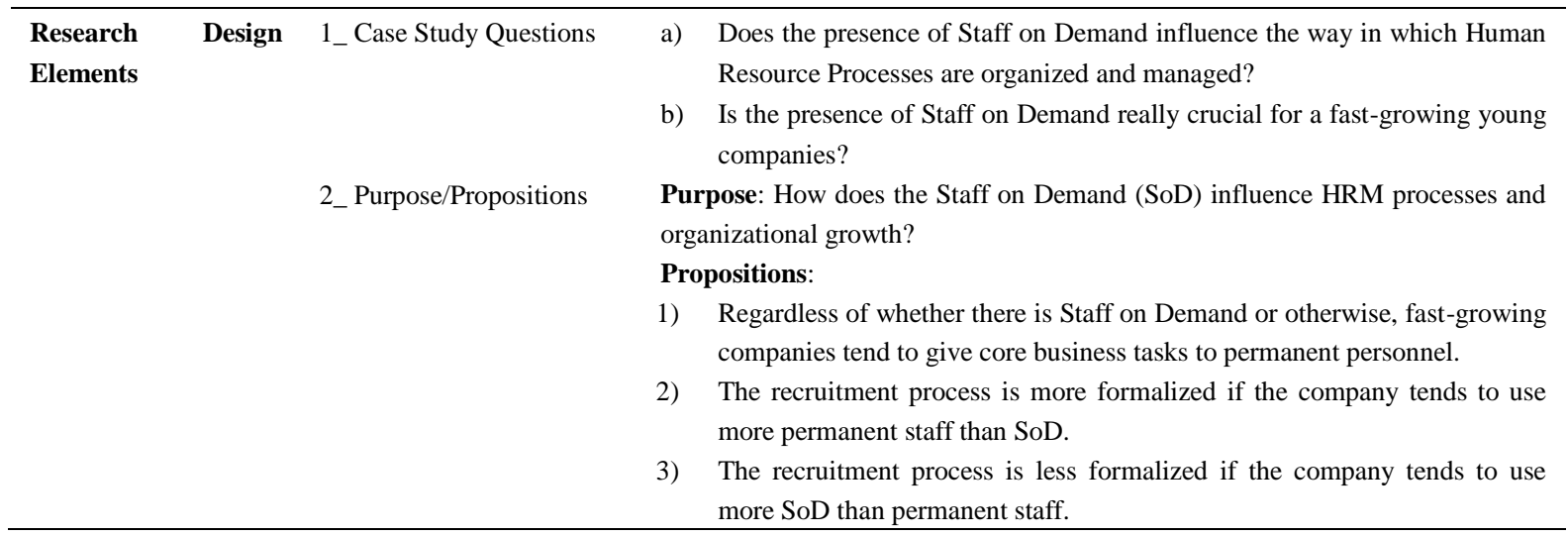




\begin{tabular}{|c|c|c|}
\hline & & $\begin{array}{l}\text { 4) The presence or absence of SoD within a company does not influence the } \\
\text { way in which HRM manages training processes. }\end{array}$ \\
\hline & & $\begin{array}{l}\text { The presence or absence of SoD within a company does not influence the } \\
\text { way in which HRM manages motivational processes. }\end{array}$ \\
\hline & & SoD does not represent a crucial element for company growth. \\
\hline & 3_ Units of Analysis & 5 Swedish organizations: \\
\hline & & 1) Weld \\
\hline & & 2) Detectify \\
\hline & & 3) Mentimeter \\
\hline & & Apptimate \\
\hline & & 5) Orbital Systems \\
\hline & & 2 aspects: \\
\hline & & a) HRM processes \\
\hline & & - recruitment \\
\hline & & - training \\
\hline & & - motivation \\
\hline & & b) Organizational Growth \\
\hline & 4_ Links between Data and & Explanation Building \\
\hline & Propositions & \\
\hline & 5_Criteria for Interpreting & Rival Explanations \\
\hline Collection of & Shorter Case & Founders \\
\hline Evidence & Interview & HR Officers \\
\hline & & CEOs \\
\hline Analysis of Evidence & Explanation Building & Narrative form \\
\hline Final report & Separate sections & One section for each company \\
\hline
\end{tabular}

Table 2. A synthesis of the main findings

\begin{tabular}{|c|c|c|c|c|c|c|c|c|}
\hline \multirow[b]{2}{*}{ Weld } & \multirow{2}{*}{$\begin{array}{l}\text { Year of } \\
\text { Foundation } \\
2014\end{array}$} & \multicolumn{2}{|c|}{$\begin{array}{l}\text { Number of Stable } \\
\text { Employees }\end{array}$} & \multirow{2}{*}{$\begin{array}{l}\begin{array}{l}\text { Number of } \\
\text { Contractors }\end{array} \\
10\end{array}$} & \multicolumn{2}{|c|}{$\begin{array}{l}\text { Perceived importance of } \\
\text { having Staff on Demand }\end{array}$} & \multirow{2}{*}{$\begin{array}{l}\begin{array}{l}\text { Future Staff on } \\
\text { Demand Trends }\end{array} \\
\text { More Contractors }\end{array}$} & \multirow{2}{*}{$\begin{array}{l}\text { Main Tasks performed } \\
\text { by Stable Employees } \\
\text { Core Business Tasks: } \\
\text { - Software development } \\
\text { - Marketing } \\
\text { - Fund raising }\end{array}$} \\
\hline & & 3 & & & High & & & \\
\hline Detectify & 2013 & 20 & & 0 & Low & & No Contractors & $\begin{array}{l}\text { Core Business Tasks: } \\
\text { - Marketing \& Sales } \\
\text { - Tech functions } \\
\text { - Hacking }\end{array}$ \\
\hline Mentimeter & 2014 & 9 & & 0 & Low & & No Contractors & $\begin{array}{l}\text { Core Business Tasks: } \\
\text { - Product development } \\
\text { - Coding } \\
\text { - Marketing \& Sales }\end{array}$ \\
\hline Apptimate & 2011 & 5 & & $3-5$ & Medium & & More Contractors & Core Business Tasks \\
\hline $\begin{array}{l}\text { Orbital } \\
\text { Systems }\end{array}$ & 2012 & 40 & & 10 & Medium & & $\begin{array}{l}\text { Not more } \\
\text { Contractors }\end{array}$ & $\begin{array}{l}\text { Core Business Tasks: } \\
\text { - Commercial } \\
\text { - Operations } \\
\text { - IT } \\
\text { - Finance } \\
\text { - HRM } \\
\text { - IT } \\
\text { - Design } \\
\end{array}$ \\
\hline & $\begin{array}{l}\text { Main Tasks I } \\
\text { by Contract }\end{array}$ & formed & Recruitme & & & Training & Motivation & $\begin{array}{l}\text { Crucial Factors for } \\
\text { the Growth }\end{array}$ \\
\hline Weld & $\begin{array}{l}\text { Core and Nor } \\
\text { Business Tasl } \\
\text { - Graphic des } \\
\text { - Accounting } \\
\text { - Generic Adr } \\
\text { Tasks }\end{array}$ & ore & $\begin{array}{l}\text { - Corporate } \\
\text { - Digital pl } \\
\text { employees } \\
\text { contractors }\end{array}$ & $\begin{array}{l}\text { website } \\
\text { tforms for stab } \\
\text { (e.g. Jobylon) a } \\
\text { (e.g. Voicebunn }\end{array}$ & $\begin{array}{l}\text { e } \\
\text { y, Fiverr) }\end{array}$ & $\begin{array}{l}\text { - Informal } \\
\text { procedures } \\
\text { - Mentorship }\end{array}$ & $\begin{array}{l}\text { No specific } \\
\text { initiatives }\end{array}$ & $\begin{array}{l}\text { - Fund raising } \\
\text { - Experimen-tation }\end{array}$ \\
\hline
\end{tabular}




\begin{tabular}{|c|c|c|c|c|c|}
\hline Detectify & & $\begin{array}{l}\text { - Corporate website } \\
\text { - Digital platforms (e.g. Teamtailor) } \\
\text { § Formal process: } \\
\text { 1) Screening } \\
\text { 2) Technical challenge } \\
\text { 3) Generic interview } \\
\text { 4) Specific interview }\end{array}$ & $\begin{array}{l}\text { - Competence } \\
\text { sharing }\end{array}$ & $\begin{array}{l}\text { - No formal } \\
\text { working time } \\
\text { - Breaks from } \\
\text { work }\end{array}$ & $\begin{array}{l}\text { - People } \\
\text { - Commitment } \\
\text { - Fund raising }\end{array}$ \\
\hline Mentimeter & & $\begin{array}{l}\text { - Recruitment Agencies } \\
\text { § Formal process: } \\
\text { 1) First interview } \\
\text { 2) Second interview } \\
\text { 3) Third interview } \\
\text { 4) Offer }\end{array}$ & $\begin{array}{l}\text { - Internal way } \\
\text { - External way } \\
\text { - Mentorship }\end{array}$ & - Job in itself & $\begin{array}{l}\text {-People } \\
\text { - Efficiency }\end{array}$ \\
\hline Apptimate & $\begin{array}{l}\text { Non-Core Business } \\
\text { Tasks }\end{array}$ & $\begin{array}{l}\text {-Corporate website } \\
\text { - Network } \\
\text { - Word of mouth } \\
\text { - Digital platforms }\end{array}$ & $\begin{array}{l}\text { - Learning by } \\
\text { doing } \\
\text { - Meetings } \\
\text { - Conferences }\end{array}$ & $\begin{array}{l}\text { - Cooperation } \\
\text { - Sense of } \\
\text { belonging }\end{array}$ & $\begin{array}{l}\text { - Team as a family } \\
\text { - Customers }\end{array}$ \\
\hline $\begin{array}{l}\text { Orbital } \\
\text { Systems }\end{array}$ & $\begin{array}{l}\text { Core Business Tasks } \\
\text { (High skilled } \\
\text { contractors) }\end{array}$ & $\begin{array}{l}\text { - Recruitment Agencies } \\
\text { - Digital platforms } \\
\text { (e.g. Workable, Youcruit) } \\
\text { - Corporate website }\end{array}$ & $\begin{array}{l}\text { "Ad hoc" } \\
\text { practices }\end{array}$ & $\begin{array}{l}\text { - Right people in } \\
\text { the right job } \\
\text { - Ownership }\end{array}$ & - Values \\
\hline & $\begin{array}{l}\text { Non-Core Business } \\
\text { Tasks (Low skilled } \\
\text { contractors) }\end{array}$ & $\begin{array}{l}\text { § Formal process: } \\
\text { 1) Job description } \\
\text { 2) Interview } \\
\text { 3) Technical questions } \\
\text { 4) Personality assessment }\end{array}$ & & & \\
\hline
\end{tabular}

\section{Main Findings and Propositions}

The businesses taken into consideration have all been founded in recent years and, with the exception of Apptimate, which is undergoing a restructuring phase, all of them have a common tendency towards growth. The element that immediately catches the eye is the different approach they have to Staff on Demand. For some, it is an important element while for others it is an unessential factor for the business. From the point of view of the tasks performed, generally we can state that tasks connected to the core business are given to stable employees. This means that greater trust is given to stable employees and that the lasting working relationship is seen as a guarantee for the successful outcome of company actions.

Proposition 1: Regardless of whether there is staff on demand or otherwise, fast-growing companies tend to give core business tasks to permanent personnel.

The startups, while all having growth in common, adopt different HRM practices. From the recruitment point of view, not all of them implement formal procedures. For Weld, the use of digital platforms is far more important. The result is not surprising, since it is a company in which contractors are prevalent. Detectify, on the other hand, also uses digital platforms but at the same time also uses a precise method of recruitment. The fact that there are four distinct recruitment phases clearly shows us how important it is to get to know the candidate in view of his or her hiring. We can deduce that a company interested in having only stable workers is more greatly focused on recruitment. It is no coincidence then if the same situation can also be found at Mentimeter which, just like Detectify, concentrates its attention to stable personnel. At Apptimate, there is no precise formalization of the recruitment phase, while it is true that here the presence of contractors is nearly equal to that of stable employees. Finally, there is also a formalization of recruitment at Orbital Systems. This type of choice appears to be coherent with the decision to hire an ever increasing number of stable workers and continuously less contractors.

In general, with regards to recruitment, we can sum up the conclusions in the following propositions:

Proposition 2: The recruitment process is more formalized if the company tends to use more permanent staff than staff on demand.

Proposition 3: The recruitment process is less formalized if the company tends to use more staff on demand than permanent staff.

With regards to training, it is not easy to identify clear tendencies. In the case of mentorship, for example, this practice is used both in Weld and in Mentimeter, in other words, two companies that from their approach to staff 
on demand point of view are completely different. A reasonable conclusion with regards to this could be that the training practices are not linked to any particular composition of Human Resources and that, consequently, they do not have any particular link to the presence or otherwise of staff on demand.

Proposition 4: The presence or absence of staff on demand within a company does not influence the way in which HRM manages training processes.

With regards to motivation, we can more or less observe the same situation concerning training. Even in this case, there does not, in fact, seem to be any notable difference in the way personnel is motivated both in companies with a high presence of staff on demand and in companies with little or no staff on demand. We can reflect, however, on at least two points.

First of all, in Weld there are no specific practices for strengthening motivation. This could mean that staff on demand is hard to motivate by factors other than economic factors. On the other hand, we can see what happens at Detectify and at Mentimeter, two companies where motivation is driven by the way in which time at work is organized and by the content of this work. In these two companies, therefore, it seems that intrinsic motivations have the better over those of an extrinsic nature. An ideal compromise is that of Orbital Systems, where motivation is strengthened by giving the "right task to the right person" (intrinsic motivation) and by owning a part of the company (extrinsic motivation). Seeing as, even in this case, we can not identify clear tendencies, we will say the same as we said with regards to training.

Proposition 5: The presence or absence of staff on demand within a company does not influence the way in which HRM manages motivational processes.

In conclusion, looking at the factors which are perceived as being crucial for company growth, nobody stated that staff on demand was an essential element for the expansion of the business. Even in cases where people are considered crucial for company growth, it has to be said that reference was always made to people who work permanently for a company. To sum up, what appears to be important for company growth is knowledge (that gained internally from other people), fund raising, customers and values. Staff on demand, therefore, appears to be important for carrying out accessory activities which are not linked to the core business but does not appear to be fundamental for growth. There is an important detail that confirms this, which is the fact that two out of five companies don not even use contractors and despite this, they are experiencing relatively rapid growth.

Proposition 6: Staff on demand does not represent a crucial element for company growth.

\section{Conclusions}

The summary contained in table 2 and the propositions put forward in the previous paragraph, only refer to the companies taken into consideration, even if we can imagine that the situation in similar companies is not very different. Contrary to what macroeconomics would lead us to believe, the importance of contractors in the current socio-economic context appears to be less crucial that predicted. Basically, young companies are happy to rely on staff on demand in case of need, but the importance of stable staff was never put into doubt. It is with stable staff, in fact, that the core team is made up of, the team that performs the most important activities of the company. In managing the principle procedures connected to Human Resources, these young fast-growing Swedish companies do not seem to be influenced by the presence of staff on demand. With the exception of recruitment, in fact, the training practices and motivational procedures do not seem to be affected by the presence of this particular category of worker. Staff on Demand seems to have little impact on both the activities of HR management and company growth. The perception of the CEOs, of HR specialists and of the Founders goes in this direction, in the sense that according to all of them, their growth is linked to factors which have nothing to do with Staff on Demand. The most important people are always stable employees because only with them can long term working relationships can be achieved and strong commitment be developed. Another explanation regarding growth factors could have its roots in core business tasks. If the growth of a company is based on particular activities and if these particular activities are carried out by stable employees, there can be no doubt that growth does not depend on contractors. Another interesting thought is the observation of future tendencies towards the hiring of freelance workers. Practically the only company that intends to hire more contractors in the future is Weld, in other words, the only company where the number of contractors exceeds the number of permanent workers.

We could say that if a startup is born with one form of Human Resource, it will tend to maintain the same structure in the future. We could ask ourselves how knowledge, especially in a tacit form, can possibly be developed and managed when people who possess it are not permanently employed by the company. One possible answer could be that of knowledge which, today, is generated and updated so very quickly that only 
highly specialized contractors can keep up with the pace of change. Such an answer, however, would be in complete contrast with this case study, as most of the companies taken into consideration have knowledge generated internally and is possessed by permanent staff. This apparent presence of contradictions will have to be studied, but it should also be said that every business model has different peculiarities that make it impossible to generalize on managerial dynamics, especially those related to knowledge management.

As a final analysis, we should not forget that environmental factors are always important. The companies taken into consideration were born and operate in Sweden, a country that has precise characteristics and that has made innovation a priority. Everything we can learn from the study of a Swedish company should be placed into a much wider picture where factors such as public infrastructures, state investments into research and development and the education system, only to mention a few, play a crucial role.

\section{Methodological Conclusions}

\section{Significance}

Yin (2013) believes that a case study can be considered as being important when it focuses on "some real-world situation that social scientists had not been able to study in the past" (p. 202).

The case study that we are proposing here focuses on a topic that has so far not been dealt with in a systematic manner by managerial literature. Some researchers, for example, assert that, today, businesses rely more and more on freelance workers for absorbing external knowledge (Nesheim, 2003; Kozica et al., 2014). In actual fact, the evidence obtained by this case study shows that the tendency is the opposite. What emerges, in fact, is a firm desire to rely on permanent workers and on knowledge obtained from within the organization. The various state of affairs found in the five Swedish companies could represent an interesting point of discussion, especially because they seem to contradict what literature has, until now, told us. Furthermore, and with regards to existing literature on this subject, we can see an almost total absence of contributions regarding the connection between HRM processes and the type of personnel used. This study singles out three processes (recruitment, training and motivation) and pairs them to two distinct categories of Human Resource (stable employees and staff on demand).

\section{Completeness}

According to Yin (2013), there are some aspects that have to be taken into consideration in order for a case study to be considered as being "complete". A crucial aspect is described in this statement: "The complete case is one in which a researcher gives clear attention to the boundaries of the case - that is, the distinction between the phenomenon being studied and its context" (p. 202). In this study, we tried to clearly define both the boundaries within which the study was conducted (Sweden) and the individual features of these businesses (company's founded in recent years and that showed wide margins for growth).

\section{Sufficient evidence}

According to Yin (2013), a case study that is presented in an appropriate manner "should enable a reader of the case study report to reach an independent judgment regarding the merits of your case study and its findings" (p. 205). With this present case study, we have tried to supply a sufficient amount of information that could inspire thought and encourage further study of the themes dealt with in the future. The organizations taken into consideration represent a small sample that does not allow wider generalization. It is, however, a wide enough sample for representing a microcosm which, at the present moment, still remains widely unexplored.

\section{Future Research Development}

There are a lot of areas on which future research regarding fast-growing companies could focus itself. Above all, it would be interesting to carry out quantitive studies on the impact that Staff on Demand has on Human Resource management processes and on the growth of companies, even if at the moment there do not appear to any data bases that gather comprehensive data on this category of worker. From this point of view, it should be said that it is difficult to estimate how many contractors there are in any company and at any one time, because we are dealing with numbers that are continuously changing and that can alter from one month to another and from one week to another.

Another interesting front could be that of the procedures of Human Resource management taken into consideration. In this paper we have considered recruitment, training and motivation, but there are evidentially a large number of other management phases that concern HRM and that are equally interesting.

And as further development, there should be research into the way in which knowledge is created and generated in fast-growing companies and, above all, into the way in which the presence of Staff on Demand influences 
knowledge management.

And further still, it would be useful in the near future to study once again the companies taken into consideration here to compare them to their situation in time 1 and to their situation in time 2 , in order to understand what has changed and, above all, why.

Finally, it would also be interesting to learn what happens in other countries and to duplicate the same case study to other countries. For example, we could try to understand what impact Staff on Demand has on young Italian, German or French startups.

All of this would certainly enrich the panorama of research into young fast-growing companies and would allow us to understand how these types of companies are changing our world today.

\section{References}

Alakavuklar, O. N. (2009). "We are family". A critical organizational discourse analysis. International Journal of Business and Management, 1(1), 1-10.

Argote, L., McEvily, B., \& Reagans, R. (2003). Managing knowledge in organizations: An integrative framework and review of emerging themes. Management Science, Special Issue on Managing Knowledge in Organizations: Creating, Retaining, and Transferring Knowledge, 49(4), 571-582. https://doi.org/10.1287/mnsc.49.4.571.14424

Bandura, A. (1977). Social learning theory. Prentice-Hall, Engelwoods Cliffs, NJ.

Ben-Roy, D., Pi-When, Y., \& Madsen, J. (2016). Exploring the relationship among human resource flexibility, organizational innovation and adaptability culture. Chinese Management Studies, 10(4), 657-674. https://doi.org/10.1108/CMS-01-2016-0022

Benwell, M. (2014). Stockholm is rivaling Silicon Valley with a hotbed of technology start-ups. Independent, December 17.

Boxall, P., Hutchison, A., \& Wassenaar, B. (2015). How do high-involvement work processes influence employee outcomes? An examination of the mediating roles of skill utilisation and intrinsic motivation. The International Journal of Human Resource Management, 26(13), 1737-1752. https://doi.org/10.1080/09585192.2014.962070

Brotheridge, C. M., \& Lee, R. T. (2006). We are family: congruity between organizational and family functioning constructs. Human Relations, 59(1), 141-161. https://doi.org/10.1177/0018726706062761

Burke, A. (2015). The handbook of research on freelancing and self-employment. Senate Hall Aacdemic Publishing, Dublin, IRELAND.

Collier, D. W. (1969). Solving the Research Department's interface problems. Management Review, 58(9), 65-69.

Don-Solomon, A., \& Tiebiri, J. E. J. (2015). Talent management and organizational growth. A survey on selected registered companies in Bayelsa state, Nigeria. European Journal of Research and Reflection in Management Science, 3(4), 74-89.

Eisenhardt, K. M. (1989). Building theories from case study research. Academy of Management Review, 14(4), 532-550. https://doi.org/10.2307/258557

Eisenhardt, K. M., \& Graebner, M. E. (2007). Theory building from cases: opportunities and challenges. The Academy of Management Journal, 50(1), 25-32. https://doi.org/10.5465/amj.2007.24160888

Eisenhardt, K. M., \& Martin, J. A. (2000). Dynamic capabilities: what are they? Strategic Management Journal, $21(10-11)$,

1105-1121. https://doi.org/10.1002/1097-0266(200010/11)21:10/11<1105::AID-SMJ133>3.0.CO;2-E

Fonti, F., \& Maoret, M. (2016). The direct and indirect effects of core and peripheral social capital on organizational performance. Strategic Management Journal, 37(8), 1765-1786. https://doi.org/10.1002/smj.2409

Frick, W. (2014). Innovation, then and now. Harvard Business Review, 92(10), 118-119.

Gaitzsch, S. (2016). Sweden, the land of the unicorns. Technologist. Retrieved from http://www.technologist.eu/sweden-the-land-of-unicorns/

Ghorashi, H., \& Sabelis, I. (2013). Juggling difference and sameness: Rethinking strategies for diversity in $\begin{array}{llll}\text { organizations. } & \text { Scandinavian Journal of }\end{array}$ 
https://doi.org/10.1016/j.scaman.2012.11.002

Grindrod, S. (2016). Mentoring is now changing the workplace through technology. Employment Relations Today, 43(3), 39-44. https://doi.org/10.1002/ert.21571

Heimerdinger, S. R., \& Hinsz, V. B. (2008). Failure avoidance motivation in a goal-setting situation. Human Performance, 21(4), 383-395. https://doi.org/10.1080/08959280802347155

Ismail, S. (2013). Exponential Organizations. Why new organizations are ten times better, faster and cheaper than yours (and what to do about it). Diversion Books, New York.

Johns, T., \& Gratton, L. (2013). The third way of virtual work. Harvard Business Review, 91(1), 66-73.

Knowledge@Wharton. (2015). How Stockholm became a “Unicorn Factory”. Knowkedge@Wharton. Retrieved from http://knowledge.wharton.upenn.edu/article/how-stockholm-became-a-unicorn-factory/

Kozica, A., Bonss, U., \& Kaiser, S. (2014). Freelancers and the absorption of external knowledge: Practical implications and theoretical contributions. Knowledge Management Research \& Practice, 12(4), 421-431. https://doi.org/10.1057/kmrp.2013.2

Locke, E. A., \& Latham, G. P. (1990). A theory of goal setting and task performance. Prentice Hall, Englewood Cliffs NJ.

Malone, T. W., Johns, T., \& Laubacher, R. J. (2011). The age of hyperspecialization. Harvard Business Review, 89(7), 56-65.

Manz, C. C., \& Sims, H. P. Jr. (1981). Vicarious learning: the influence of modeling in organizational behavior. Academy of Management Review, 6(1), 105-113. https://doi.org/10.2307/257144

Marfelt, M. M., \& Muhr, S. L. (2016). Managing protean diversity. International Journal of Cross Cultural Management, 16(2), 231-251. https://doi.org/10.1177/1470595816660120

Meyer, J. P., \& Allen, N. J. (1991). A three-component conceptualization of organizational commitment. Human Resource Management Review, 1(1), 61-89. https://doi.org/10.1016/1053-4822(91)90011-Z

Miller, R., \& Côté, M. (1985). Growing the next Silicon Valley. Harvard Business Review, 63(4), 114-123.

Narayanan, A. (2016). Talent management and employee retention: Implications of job embeddedness. A research agenda. Journal of Strategic Human Resource Management, 5(2), 34-40.

Nesheim, T. (2003). Using external work arrangements in core value-creation areas. European Management Journal, 21(4), 528-537. https://doi.org/10.1016/S0263-2373(03)00075-6

Odongo, M. S., \& Datche, O. (2015). Effects of strategic planning on organizational growth. International Journal of Scientific and Research Publications, 5(9), 1-15.

Park, J. H., Newman, A., Lili, Z., Chendong, W., \& Angus, H. (2016). Mentoring functions and turnover intention: the mediating role of perceived organizational support. The International Journal of Human Resource Management, 27(11), 1173-1191. https://doi.org/10.1080/09585192.2015.1062038

Süß, S., \& Kleiner, M. (2010). Commitment and work-related expectations in flexible employment forms: An empirical study of German IT freelancers. European Management Journal, 28(1), 40-54. https://doi.org/10.1016/j.emj.2009.02.002

Tovstiga, G., \& Tulugurova, E. (2009). Intellectual capital practices: A four-region comparative study. Journal of Intellectual Capital, 10(1), 70-80. https://doi.org/10.1108/14691930910922905

Trougakos, J. P., Hideg, I., Hayden, C. B., \& Beal, D. J. (2014). Lunch breaks unpacked: the role of autonomy as a moderator of recovery during lunch. Academy of Management Journal, 57(2), 405-421. https://doi.org/10.5465/amj.2011.1072

Yin, R. K. (2013). Case study research: Design and methods (5th ed.). SAGE Publications.

\section{Copyrights}

Copyright for this article is retained by the author(s), with first publication rights granted to the journal.

This is an open-access article distributed under the terms and conditions of the Creative Commons Attribution license (http://creativecommons.org/licenses/by/4.0/). 